\title{
Robert Rumiński
}

\section{Social determinants and their}

\section{influence on entrepreneurship in the light of experiences of the United States}

Entrepreneurship is a multi-context phenomenon with many various meanings. Interdisciplinary nature of this phenomenon influenced the creation of different measures designed to reflect the level of entrepreneurship in each of the disciplines of science. Social determinants have a significant impact on the development of entrepreneurship. In order to fully understand entrepreneurship, it is necessary to take the socio-cultural aspect into account. This aspect constitutes one of the key elements of the competitive advantage of enterprises.

Due to the large number and diversity of the measures, there are attempts to present determinants of entrepreneurial behavior. There is a well-developed literature on social and cultural factors influencing entrepreneurship. The literature on the subject has repeatedly discussed factors influencing the development of an enterprise. Much attention is paid to the external factors which determine the growth of entrepreneurship [Skawińska, 2012]. However, the attention is also paid to the social and cultural factors that are the internal factors determining the firm's competitiveness. Many theories indicate that the socio-cultural environment influences behaviors and decisions of individuals in their economic lives, including decisions about entrepreneurship. Never- theless, social attitudes are sometimes over-emphasized and their role is based on the misconception that there is one homogeneous value system shared by members of a given society. The classification recognizes entrepreneurial approach and introduces the following measures of entrepreneurship [Janczewski, 2005]:

- basic (economic performance),

- psychological (personal characteristics and soft skills),

- using management science (entrepreneurship as a sort of managerial behavior),

- cultural and social (factors).

Entrepreneurs are shaped by the social system and culture of people - so called socio-cultural business environment [Azim, 2008; Zeffane, 2014] and the business environment significantly influences the entrepreneurial intention of individuals [Akpor-Robaro, 2012;

Arasti, et al., 2012; Boggs, 2004; Inglehart, 1997]. It is widely acknowledged by numerous researchers that socio-cultural factors have a significant effect on the entrepreneurial process [Alvarez, $\mathrm{Ur}$ bano, 2011; Castrogiovanni, et al., 2011; Coduras, et al.; 2008; Knörr, et al., 2013; Liñán, et al. 2011, Noguera, et al., 2013, Thornton, et al., 2011]. Individuals are embedded in their local entrepreneurial environment and it was proved by numerous researchers that this environment 
influences an individual's decision about starting his/her own business [Mueller, 2006; Davidsson, Honig, 2003; Minniti, 2004, 2005]. Social factors influencing entrepreneurship may be equally important as financial factors, information or technical support [Gnyawali, Fogel, 1994]. F.R. David [2013], P.T. FitzRoy et al. [2012] indicated that the social context includes variables such as: population size, growth, age and ethnic mix, life expectancy, migration, income, lifestyle changes, social mobility, education and religion. Moreover, personal contacts (networking among entrepreneurs) which is oftentimes referred to as social capital play an important role in the decision making of business owners [Román, et al., 2013].

In entrepreneurial research the cultural factors have been emphasized quite strongly and the culture has been researched the most in association with entrepreneurship. Most of the behavioral studies have been influenced by G. Hofstede [1995, 2010] who defined culture as the collective programming of the mind whereas E.T. Hall [1976] points to the culture communication's perspective. G. Hofstede's [1980] Cultural Dimension Model has been widely accepted as a model to explain cultural factors. $\mathrm{He}$ conducted one of the most comprehensive studies of how values in the workplace are influenced by culture. R.D. Russell [2004] pointed out that the creation of a new business venture is always judged by the members of a certain cultural community and that "the rules of the game" are different for various cultures, influencing the social status of an entrepreneur. J.C. Hayton, et al. [2002] claim that cultural characteristics transform the context which influences entrepreneurship within different cultures. F. Trompenaars, C. Hampden-Turner [2012] focus in their research on the fact why people from a certain culture are more successful in a different culture when starting a business, whereas V. Gupta, et al. [2004] tend to explain entrepreneurial leadership styles and distinguish the roles of entrepreneurial leaders summarized in the entrepreneurial leadership score. In their cross-cultural studies they tried to relate the cultural dimension to entrepreneurial attitudes and entrepreneurial activity.

The socio-cultural entrepreneurship environment consists of the elements of the social system and culture of people which positively or negatively affect entrepreneurial emergence, behavior as well as performance. Social and cultural elements of entrepreneurial development undoubtedly influence the creation of entrepreneurial attitudes and actions and influence the shaping of networks of personal and organizational connections, the perception and use of opportunities, and the willingness to take risks. They are evidenced by the developed norms of behavior, social behavior and value system. The effectiveness of entrepreneurs is not only a result of their economic activities and events, but it is also a result of changes in values and attitudes as well as changes in demography and in the level of education. Thus, economic decisions are conditioned by norms and values of entrepreneurs, including cultivated traditions and religions. The determinants of enterprise development related to entrepreneurs themselves are associated with demographic factors such as age, gender, knowledge/know-how, vocational education and experience as well as cultural factors. The personality traits of the owner, such as his risk-taking inclination (risk aversion), motivation, persistence in pursuit of his/her goals, and managerial competences, are significant. These elements determine the entrepreneur's economic activity and are therefore called primary factors. They incorporate a range of predispositions necessary for running a business, influencing the expectations 
of the owners regarding the possibility of achieving certain tangible and intangible benefits from doing business. This is particularly important in small and mediumsized enterprises, where the majority of owners are both managers and controllers [Karpowicz, 2013].

There are also theories that disregard the above. S. Shane [2003], a researcher at the University of Maryland, points out that business idea is the key element of entrepreneurship. This idea is not dependent on age, on education profile, or on the intensity of its search. The business idea is defined by Shane as an opportunity whose appearance is not dependent on the search, since the opportunity is by definition unpredictable until it is accidentally discovered. Nevertheless, most of the researchers in their studies take into account the above mentioned socio-cultural factors and their significant direct or indirect impact on entrepreneurship.

The purpose of this paper is to study the role and the influence of social determinants on development of entrepreneurship in the light of experiences of the United States - a cradle of entrepreneurship and innovation. Both sociology and culture play important role and highly influence the stimulation of American entrepreneurship development. The paper puts special emphasis on the key variables in traditional entrepreneurial studies such as: gender, race, age and education (social measures), their influence on entrepreneurship and role in enterprise development. It is also concerned with the influence of culture on entrepreneurial landscape.

A large number and diversity of the entrepreneurship measures contribute to the attempts of defining the determinants of entrepreneurial behavior. In order to fully understand entrepreneurship and entrepreneurial behavior it is necessary to take the socio-cultural aspect into account. The following hypothesis was adopted in the paper: socio-cultural determinants (the above mentioned variables) have a significant influence on entrepreneurship development in the U.S., including the entrepreneurial attitudes, behaviors and individuals' decisions about entrepreneurship. The contribution of the paper into the subject area is demonstrated in the verification of the research hypothesis posed, presentation of empirical findings, their analysis, and in the conclusions of cognitive character concerning both social and cultural elements of entrepreneurial development. The author synthesizes the results of many empirical studies. A separate presentation of any of the variables accepted in the hypothesis (social and cultural) would simply duplicate existing sources. However, their aggregation and combined comparison make it possible to identify important relationships between the sphere of business culture and entrepreneurship.

The characteristic feature of highly developed countries is the relatively slow population growth rate due to low birth rates and generally restrictive immigration policies, especially after 1970 . One of the few exceptions in this regard is the U.S. In the last few decades there has been a large increase in population in the U.S., which contributed to economic development through the creation of demand, as well as progress in various areas of socioeconomic development. This progress has largely been achieved by attracting highly qualified human resources that have contributed to the deployment of new technologies. The above facts were of great importance for the development of entrepreneurial behaviors and business development. The U.S. is an unusual country, and its rather short history abounds in the major events that shaped its character and entrepreneurial environment. It is a cradle of entrepreneurship and individualism is a central feature of the U.S. culture. It is 
one of the main values that played a key role in shaping the character of the nation and influenced all the fields of economics, including entrepreneurship [Hao, 2015]. Thanks to this, entrepreneurs enjoy a high status regardless of whether or not they are successful. Historical, social and cultural determinants play a significant role in the development of entrepreneurship in the U.S., making this country a very interesting research field. Over the decades, the country has attracted people looking for better economic conditions. Today, despite the recent crisis and great social inequalities, America still attracts many people with the prospect of wealth and great opportunities for entrepreneurs. It remains a reference point for other countries, an unsurpassed model and guide in the economic world.

\section{Gender}

Social determinants are particularly important in the development of women's entrepreneurship, whose economic activity continues to be strongly influenced by social stereotypes and gender roles. The socially and culturally stigmatized stereotype influences the willingness of women to run their own businesses. High percentage of women among entrepreneurs and the positive stereotype of women entrepreneurs may indicate that in this sphere of professional activity a new pattern of occupation is being created - a professionally active woman of success [Godowska, 2011].

Among the entrepreneurs and managers in the U.S. men predominate. The BERR [2008] study found that highgrowth firms in the U.S. have a strikingly high propensity to be founded by males (Report prepared for the OECD/DBA, 2012). Women owners tend to have fewer years of industry experience, as well as startup experience. Fewer role models for women may be associated with gender stereotyping and entrepreneurship has been more often associated with men than women and has been seen as a masculine behavior reinforced by the media [Bruni, et. al., 2004; Bird, Brush, 2002]. Women and men in the U.S. have other possible sources of employment since most entrepreneurship is opportunity-driven rather than necessity-based. However, many societies attribute women to housebound and family-related roles marking entrepreneurship as a less-desirable career choice for women [Pfau-Effinger, 2004]. Therefore, women are oftentimes expected to care for family rather than play a role of an entrepreneur. Less social support for women causes less confidence in their entrepreneurial activities.

Despite the gender stereotyping, en-

Figure 1 Perceived opportunities among women and men in the U.S.

$60 \%$

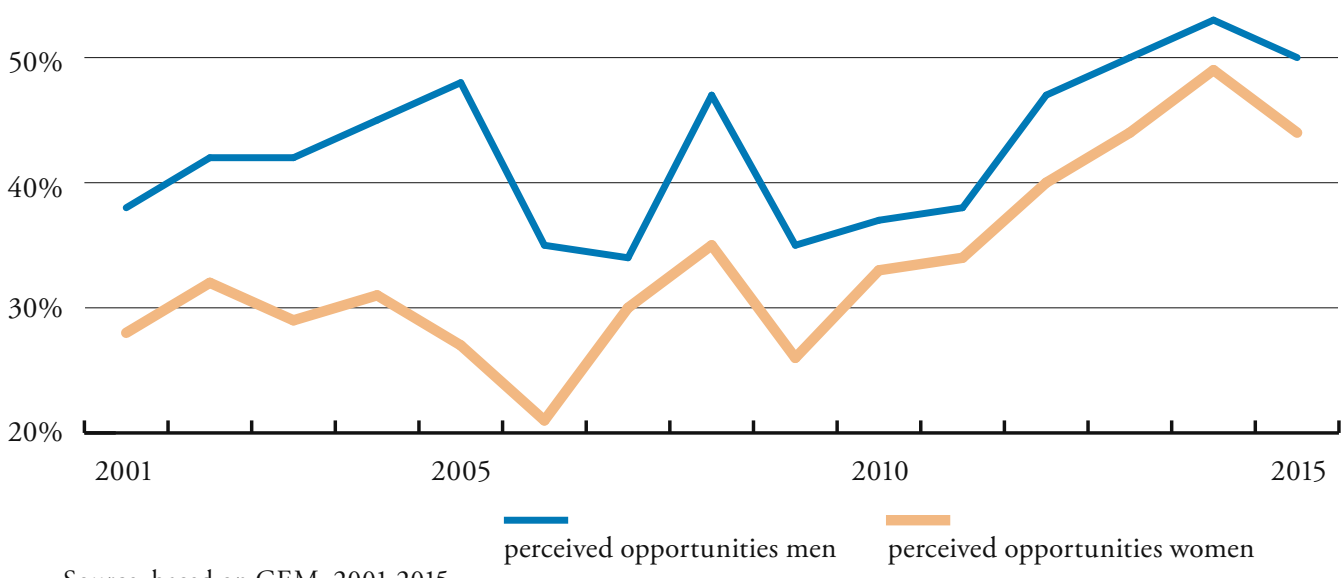

Source: based on GEM, 2001-2015. 
trepreneurial women and their businesses play a significant role and women's entrepreneurship has been an important component of the U.S. economy. Women are starting businesses at a greater rate than in many other innovation-driven economies. There are over $11.3 \mathrm{~m}$ enterprises owned by women, employing nearly $9 \mathrm{~m}$ people, and generating 1.6 usd trillion in sales (2016). It is expected that the number of women-owned and women-led businesses increase by more than $50 \%$ over the next 5 years. According to the 2016 Kauffman Index of Startup Activity [Pofeldt, 2017], women currently make up $40 \%$ of new entrepreneurs in the U.S. - the highest percentage since 1996. The women's interest in the startup scene is sparked by expanding financing options, marketplace trends and a greater access to mentors. Women-owned enterprises account for $31 \%$ of all privately held business ventures and contribute $14 \%$ of employment and $12 \%$ of revenues [NWBC, 2015]. The entrepreneurial spirit among women is well due to favorable legal environment as well as a market positive response.

Men have greater growth aspirations than women, however, within the last decade the gap in expectations for growing a business has narrowed significantly. Currently women and men hold nearly equal expectations. Gender gaps in perceived capabilities, fear of failure and perceived opportunities influence the intentions to start a business and start-up rates [Kelley, et al., 2014]. Approximately 55\% of men perceive business opportunities compared to $44 \%$ of women and this disparity has remained steady over the past 5 years [Kelley, et al, 2014] - Figure 1.

One of the factors explaining the gap between women and men is related to the probability of having interrupted career pathways and therefore having less confidence in entrepreneurial skills and capabilities [Brush, et al., 2004]. An- other factor is a capability to start a business - perceived capabilities for starting a business by men and women vary significantly (62\% of men believe they are capable compared to $50 \%$ of women). One may draw a conclusion that men have more confidence in their ability to start a business or have had more training and experience. Last but not least is a fear of failure including fear of social failure, personal failure, monetary failure and other concerns. Women exhibit a higher perceived rate of failure of $33 \%$ to $27 \%$ for men, however, this differential is narrower in 2015 than in 2014 [GEM, 2015]. The cultural landscape has changed and there has been a shift in the conversation about women's entrepreneurship resulting from an increase in women launching their companies and the recognition of their impact on the economy by business press [NWBC, 2015].

As far as the access to financing is concerned, historically, women have not had equal access to financial markets due to the systemic bias against women business owners (Research by the Global Initiative for Women's Entrepreneurship Research). Women are more likely to start businesses in consumer products and services, using less funding to get started. They often use personal savings to begin a new business and bank loans are underutilized. The available resources are often influenced by household size, the household head and the health of the household members [Brush, Manolova, 2004]. Women are more likely to outperform their men counterparts in meeting crowdfunding goals, e.g., to succeed at a campaign. [Greenberg, Mollick, 2016]. They have been trending towards alternative lending sources for access to capital. Nonetheless, there is a gender gap in equity financing (women receive $1 \%$ of VC financing compared to $4 \%$ of men). Women entrepreneurs face numerous barriers regarding the growth, including an inability to compete with large businesses. 
Moreover, they still face a significant wage gap and frequently have smaller amounts of startup capital than their male peers on average, access to half as much capital as men.

Female entrepreneurs are more likely to set up business ventures in consumeroriented sectors whereas male entrepreneurs are equally likely to start a business in the consumer-oriented and businessservices sectors (see Figure 2).

Men are more likely to work in construction and women are more likely to be found in enterprises serving consumers directly. The breakdowns are similar to the general population of the U.S. businesses, where retail trade and consumer services are prevailing.

The amount and source of startup funding influences the choice of particular sector. Taking into consideration the fact that women start their businesses with half of what men do, their choice is possibly linked to less capital consuming sectors such as consumer services. Starting a business venture in manufacturing or business services requires much more financial resources. Smaller accumulation of financial capital by women may be related to their career breaks and may result in lower equity invested in startups [Arun, et al., 2004].

\section{Race}

The anthropological perspective in entrepreneurship research is related to the identification of cultural associations with entrepreneurship. Ethnicity affects the attitudes and behavior of entrepreneurs, and culture influences the entrepreneurial attitudes of members of the community, as Max Weber first saw, describing the relationship between economic activity and religion [Brzozowska, 2016]. Ethnic groups play an important role in the development of entrepreneurship. They form jointly accepted standards of entrepreneurial behavior acting on the principle of "mutual support" and benefit from personal relationships between members of a given group, giving some guarantees of security and reducing the risk of unethical behavior [Safin, 2003].

There are certain differences in the levels of entrepreneurship among different ethnic groups in the U.S.. Ethnic entrepreneurship will have a significant impact on both the U.S. and the global economy in the coming decades. Immigrants are twice as likely to be entrepreneurs compared to native-born Americans, however, 9 in 10 immigrant entrepreneurs are lowincome entrepreneurs [Slivinski, 2015].

The race of business owners in the U.S. can be broadly grouped into several categories: African American ("Black"),

\section{Figure 2 Female and male activity - industry sector distribution}

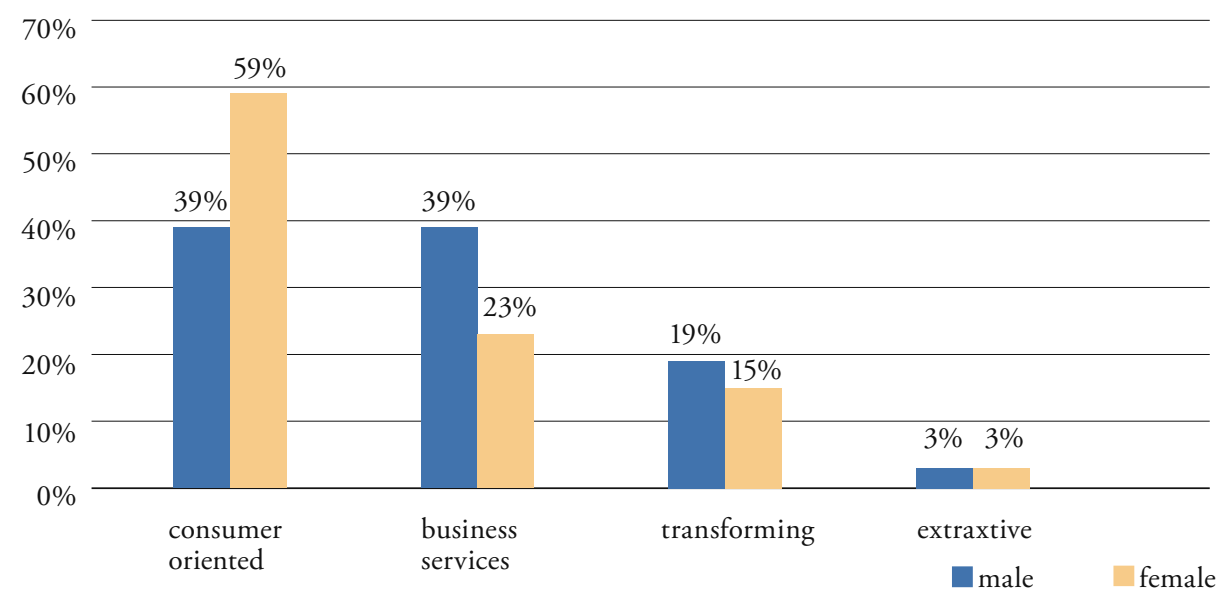

Source: based on: GEM 2015, p. 35 
Asian, Hispanic, White (Caucasian). The U.S. Census Bureau recognizes more detailed classification of racial categories:

- White American,

- Native American and Alaska Native,

- Asian American,

- African American,

- Native Hawaiian,

- Other Pacific Islander.

It also classifies Americans as "Hispanic or Latino" and "Not Hispanic or Latino" which identifies Hispanic and Latino Americans as a racially diverse ethnicity, however, the U.S. Census Bureau has been inconsistent in defining these racial groups. The Native American, Hawaiian, and Pacific Islander categories are essentially understudied. According to the SBA, in 2013 black-owned enterprises represented $7 \%$ of U.S. businesses, Asian-owned firms represented only $4.3 \%$, and the share of Hispanic-owned was only $10.6 \%$ [SBA, 2013] Whiteowned and Asian-owned enterprises have lower failure rates than do black-owned and Hispanic-owned firms. $13 \mathrm{~m}$ people in the U.S. are self-employed entrepreneurs holding $37.4 \%$ of total U.S. wealth [Bucks, et al., 2006]. 5.1\% of African American and $7.5 \%$ of Latino workers own businesses whereas white and Asian workers own more than $11 \%$. Black- and Latino-owned enterprises hire fewer employees, have lower sales and have smaller payrolls than white-owned businesses. African-American and Hispanic entrepreneurs underperform compared to nonminority owners. The racial diversity of small business owners is increasing. According to the Kauffman Foundation report [2015] between 1996 and 2014 the share of white business owners decreased from $86.9 \%$ to $72.0 \%$ whereas the share of black business owners increased from $4.2 \%$ to $6.3 \%$, the share of Asian owners increased from $3.8 \%$ to $6.2 \%$, and Latino owners more than doubled - from 5.6\% to $13.5 \%$ (Figure 3).
Figure 3 Small business owners - demographic diversity in the U.S.

White
Latino
Black
Asian
Other

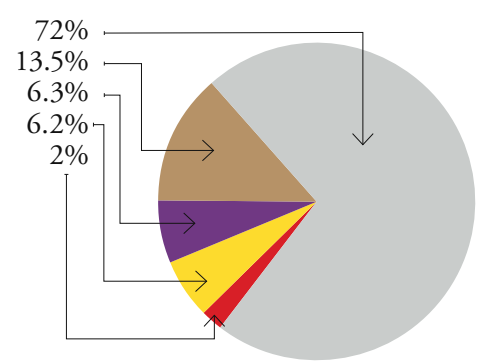

Source: based on:

The state of small business in America, Babson College, 2016.

There are 8 million minority-owned firms in the U.S. (a 38\% increase since 2007) and their combined gross receipts increased 35\% between 2007 and 2012. Over the last two decades the number of entrepreneurs increased rapidly, however, their share is still small_and their growth rate lags behind white-owned enterprises. A substantial proportion of African Americans-owned businesses are less successful, have lower profits and higher closure rates than enterprises owned by whites (U.S. Census Bureau 2014, 2016). The outcomes of Asian American-owned businesses are more similar to those of white-owned enterprises and these racial patterns in business performance have remained unchanged over the past twenty years [Fairlie, Robb, 2008] - see Figure 4.

Studies find that Asian businesses owners have better education and more start-up capital than Hispanics or Blacks [Fairlie, et al., 2008, Robb, Fairlie, 2009]. Business receipts are still dominated by White-owned enterprises. Although African Americans are more likely to set up a new business (higher propensity) they are less likely to succeed at starting the business.

As far as the access to financing (bank loans) is concerned there are some racial and ethnic gaps. Compared to white businesses, blacks and Hispanics have lower wealth levels than whites, and - as a consequence - lower equity that might be used to develop their businesses. Whites 


\section{Figure 4 Minority-owned enterprises in the U.S. by industry sectors}

Healthcare \& Social Assistance

Adminstrative Support, Waste Management \& Remediation

Professional, Scientific \& Tech

Contruction

Retail

Transportation \& Warehousing

Real Estate \& Leasing

Other

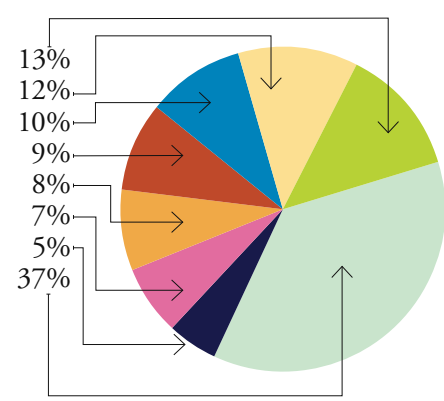

Source: based on: Fact Sheet, U.S. Minority-Owned Firms, 2016.

are more than five times as likely to receive an inheritance as blacks (36\% vs. $7 \%)$. In contrast, $80 \%$ of black parents and $70 \%$ of Hispanic parents expect to be supported by their children [Fetsch, 2016]. In case of black-owned and Hispanic-owned enterprises there are also less favorable loan application outcomes than in the case of white-owned and Asianowned firms. The above gaps result in entering the low capital consumption industries by black and Hispanic entrepreneurs and a high rate of their failures. Moreover, prior family business ownership is more frequent among Asian and white entrepreneurs than in the case of black and Hispanic ones [Bradford, Mijid, 2016].

\section{Age}

In the light of the relationship between age and entrepreneurship, an interesting concept, which was formulated in the 1960s, namely the Cattella-Horna theory, deserves attention. According to this concept, man has two types of intelligence: fluid and crystallized. Fluid intelligence (fluid reasoning) is innate, biologically mental potential, manifesting itself e.g., in the rate of matching facts and events, abstract thinking and intuitive problem solving. On the other hand, crystallized intelligence is nothing but knowledge and skills acquired over time. It manifests itself, among others, in vocabulary or logical thinking. Based on the above it can be concluded that the effect of fluid intelligence is an idea or innovation, and in the case of crystallized intelligence identification within logical steps that lead to final success. In the case of an enterprise, it will be the development of a business plan, the introduction of a product on the market, and the effective management of the business. With the development of crystallized intelligence, project management skills that are key to business are acquired.

The advantage of one or another kind of intelligence does not affect the success or lack thereof in opening one's own business. It can be concluded that the younger age (the advantage of fluid intelligence) means greater risk (lack of organizational capacity and high innovation), which means faster and unstable growth. Older age (the advantage of crystallized intelligence) indicates lower risk (having organizational capacity and less innovation), resulting in slower and more stable growth [Rokita, 2015].

Demographics is one of the most important issues affecting entrepreneurship, however, there can be no definite connection between demography and aggregate entrepreneurship. Demographic change and its analysis occupy most economic discussions, including employment policy and taxes. Over the next few decades the U.S. will have an aging population and its median age is projected to hit 40.2 in 2020 (see Figure 5). Intentions to engage in entrepreneurial activity by different age groups in the U.S. are high. Until recently, the willingness to open one's own 
company was recognized as one of the characteristics of Baby Boomers from the 70's and 90's. The young entrepreneur's enthusiasm, however, was tempered by the recent financial crisis which discouraged them from investing in new ideas. The Baby Boomers from 1946-1964 admit that financial turmoil have not significantly affected their propensity to take on business risks, which can be explained by age - older people have in mind other financial or political crises, and for young businessmen the recent collapse of the global economy was the first major warning in their lives.

The U.S. can expect a slowing labor force growth within the next several decades. Between 1990 and 2010 there was a steady fall in youth labor force participation (ages 16 to 24). It is projected to continue to 2020. Among the older age groups there is the rise in labor force participation especially over the age of 60 (both men and women) [Maestas, Zissimoupoulos, 2010]. More people are elderly and the fertility rate is falling. Since 2000, the fastest population growth has been in the group of 55-64 year old. Workforce participation rates in this group is $64 \%$ and even for the oldest group (aged 65 to 74 ) is still high and amounts to $26 \%$ which indicates that entrepreneurship is a key means of employment for those still working in their older years [GEM, 2015].

The working age population as a share of total population will decline over the next two decades. These trends influencing the labor force and general population will increase the dependency ratio [King, Soneji, 2011]. An aging population (individuals over 55) tend not to become new entrepreneurs and are presumed to have higher opportunity costs and higher risk aversion. Nevertheless, there are reasons to expect that entrepreneurship may increase. One of them is that until 2030, the number of the U.S. citizens in their "peak age" for entrepreneurship (30s and 40s) will be bigger than ever before. Another factor is a continued immigration mitigating general aging by higher rates of business creation. Last but not least is that demographic trends create numerous entrepreneurial opportunities [Stangler, Spulber 2013].

The data clearly show that statistically better business people are older people, especially those who have failed before, implementing one of their ideas. Even the youngest businessmen, taking the most important positions in the company, are more likely to choose experienced employees. The average age of an employee promoted to CEO in 500 largest American companies was 52.9 years [Standard \&

Figure 5 Labor force participation rates in 1999, 2000, 2010 and 2020 (\%)

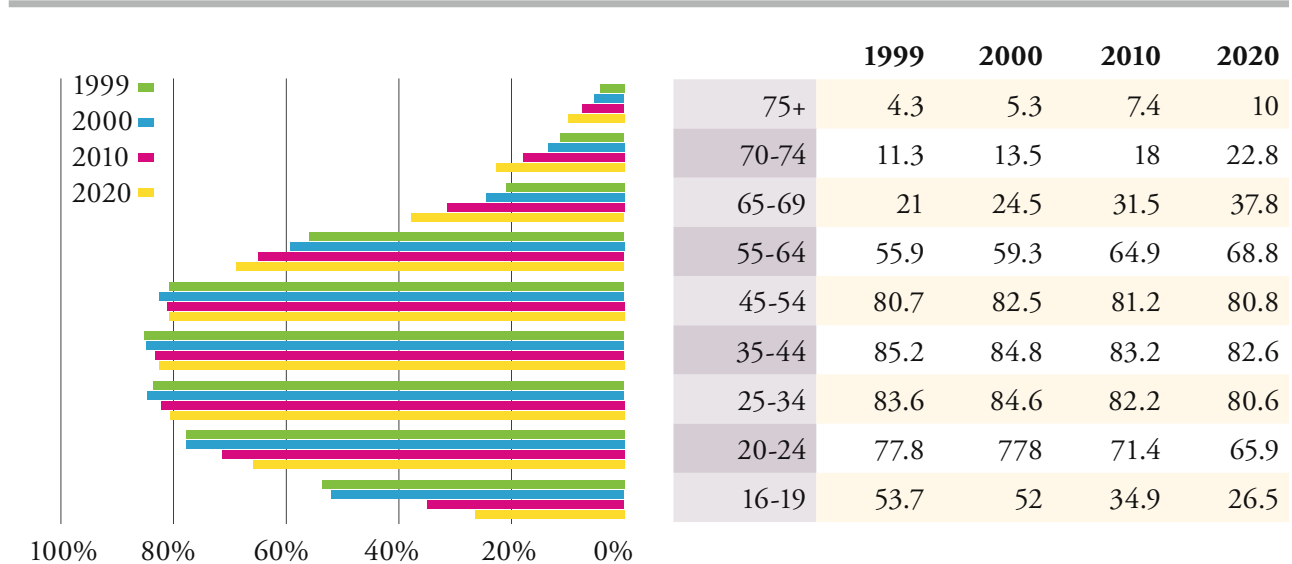

Source: based on: Toossi M., Labor force projections to 2020: a more slowly growing workforce, "Monthly Labor Review", 2012. 




Source: own elaboration based on: The Kauffman Index Startup Activity National Trends 2015.

Poor's, 2010]. According to the Kauffman Index Startup Activity [Fairlie, Morelix, 2015], the average startup age in business has clearly increased. In 2014, the highest share in the startup population was in the 45-54 age group (26.6\%), a slight increase compared to $2000(23.6 \%)$ - see Figure 6.

The largest increase in almost two decades was recorded among business people aged 55-64, whose share went from $15.4 \%$ in 2000 to $25.8 \%$ in 2014 . The largest decline occurred among people aged 20-34, whose share decreased from $33.7 \%$ to $24.7 \%$.

New entrepreneurs entering the market use their experience, but also contacts that help in completing the team, as well as in finding a potential investor. Equity capital which the entrepreneur is willing to invest is very important - mature people have a certain advantage over young people because of having enough funds to start a business or financial security. Older age groups have higher levels of self-employment and it rises with age [Hipple, 2010; Karoly, Zissimopoulos, 2004; Stangler, Spulber, 2013]. Based on the above, it can be concluded that mature people are the group that has the best chance of success in business. The cases of Mark Zuckerberg or Bill Gates are exceptions to the rule. Due to the exceptionally low age of entrepreneurs, at the time of setting up their companies, these cases are particularly eagerly referred to by the me- dia [Goodwin, 2015]. Last but not least is the fact that age-related patterns in entrepreneurial activity may explain the gender gap described in the previous section. Men report high rates of entrepreneurship across their working ages whereas women report low activity in the younger and older age groups [GEM, 2015].

\section{Education}

Education is a vital factor influencing the entrepreneurship and business growth. It is an acquired attribute unlike other demographic variables discussed above. The human capital comprises of such variables as (inter alia) level of education, type of education, length of experience, having varied experiences, being occupied in certain types of activities of the non routine type and having been an entrepreneur before [Backman, Karlsson, 2013]. Both general and specific knowledge and skills may be useful for running a successful business.

The knowledge resources of both entrepreneurs and their employees are an essential element of competitive advantage [Jiméneza, et al., 2015]. Formal education is an important component contributing to the accumulation of knowledge and skills useful to entrepreneurs. Higher levels of education increase the probability of becoming self-employed and the financial success of individuals [Marshall, Samal, 2006]. 
Tertiary education has a positive influence on entrepreneurship by its contribution to the higher level of business owners' self-confidence, lower perceived risk and enhanced human capital [Shane, 2000]. Educated entrepreneurs have greater potential, more cognitive skills and have an advantage in the process of the discovery, evaluation and successful exploitation of opportunities [Davidsson, Honig, 2003].

J.R. Baum et al. [2001] and J.R. Baum and E.A. Locke [2004] have examined the entrepreneur characteristics including the educational background and his/her prior experience [Klepper, 2009; Agarwal, et al., 2004] and they concluded that these factors have a positive impact on firm growth, especially new and small enterprises. Education and background experience enable the entrepreneur to identify key sources of information and know-how. Firms with such entrepreneurs exhibit better growth performance than those without such entrepreneurial backgrounds [Audretsch, 2012]. Moreover, R. Harding [2002] suggested that human capital has a direct influence on the entrepreneur's ability to secure financial capital for business ventures. A large literature has emerged on the impact of education on entrepreneurial profits. According to J. van der Sluis, and M. van Praag [2008] an added year of education raises entrepreneurial profits by $6.1 \%$ (on average) in developed countries and $5.5 \%$ in developing economies. However, the literature does not exhibit an emphasis on identifying causal effects [Kolstad, Wiig, 2011].

According to the U.S. Small Business Administration, 39\% of business owners in the U.S. have a bachelor's degree or higher, 33\% have at least some college and $28 \%$ have at least a high school education (Demographic Characteristics of Business Owners and Employees: 2013) (see Figure 7). It has been observed that high tech firms based in the U.S. have the highest education levels and the highest levels of industry and startup experience. Enterprises that were incorporated and those with teams and owners with higher education levels are more likely to apply for a new bank loan [Robb, 2013].

The study Education and Tech Entrepreneurship [Wadhwa, et al., 2008] interviewed nearly two thousand startup founders in the U.S, trying to find their common features. It turned out that $90 \%$ of them had at least a bachelor's degree, mostly in business or finance (33\%), engineering (28\%) and computer science (9\%). An interesting correlation has been found that the level of education (degree) affects the moment when a new company is founded. In the case of people holding a master's degree, the establishment of a new company took 5 years after graduation. In the case of bachelor's degree holders it was 17 years, and $\mathrm{PhD}$ degree - as many as 21 years. Moreover, the BERR [2008] study noted that high growth enterprises tend to have management teams and founding entrepreneurs with higher educational level and skills than their lower growth counterparts.

As mentioned above, the majority of entrepreneurs in the U.S. are highly educated. Figure 8 shows that $80 \%$ of the U.S. entrepreneurs have a college degree or higher level of education. The largest group of entrepreneurs with post-secondary education among the five states is in Texas, however, the difference between Texas, California and Ohio is very small. The largest share of business owners with graduate-level education is in New York, but at the same time this state has the smallest share of entrepreneurs with college-level education. This large disparity may be due to the high level of humancapital-intensive industries (such as insurance and finance) that are located in this area [GEM, 2015]. 
Figure 7 Small business owners - education diversity in the U.S.

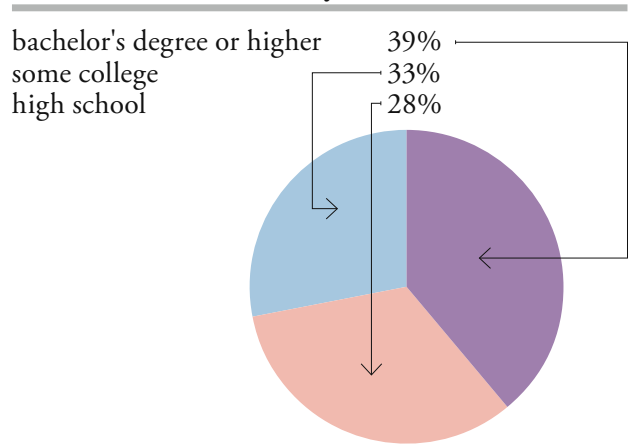

Source: based on: The state of small business in America, Babson College, 2016.

Another factor that should be taken into consideration is related to racial disparities in education levels of business owners leading to racial disparities in business outcomes. Asians are the leaders as it comes to college education. Nearly $50 \%$ of them, whether born abroad or in the U.S., have a tertiary education, whereas in the case of blacks it is less than $20 \%$ and nearly $30 \%$ in the case of whites [Fairlie, Robb, 2008] . Thus, white and Asian entrepreneurs have higher education levels and more years of managerial experience than black and Hispanic entrepreneurs do, though, the latter have recently made some improvements in their education and business experience which may reduce the gap in performance of startups. Lower education, slightly lower average industry experience and much less startup experience of black and Hispanic entrepreneurs ultimately leads to higher failure rates, and thus, lower business survival rates [Bradford, Mijid, 2016].

\section{The influence of culture on entrepreneurial landscape}

Fundamental role in the development of entrepreneurship is also played by cultural factors, including:

- systems of values and beliefs that are reflected in the observance of certain moral norms,

- entrepreneurial traditions in particular areas,
- family model and family ties,

- social climate conducive to (or not conducive to) entrepreneurship,

- trust as a cultural asset [Sztompka, 1998].

Culture is defined as a set of shared values, beliefs, and behaviors [Hofstede, 1980]. It has been gradually recognized as an important factor contributing to promotion or inhibition of entrepreneurship. In the culture of each society there are values that are associated with economic activity, such as independence, willingness to take risk, activity, ethos of work, independence, or acceptance for wealth diversity [Cierniak-Szósta, 2008]. These values indicate the degree to which a society considers entrepreneurial behaviors. The cultural context influences the ways of thinking about business, form of the practice and attitudes towards entrepreneurs which are treated as models for action [Polak, Haber, 2014; Casson, Godley, 2000]. Entrepreneurs are shaped by the factors of their socio-cultural environment and entrepreneurship is a social process that is culturally and historically determined.

Entrepreneurial culture is shaped by consequences of history, ideological beliefs and practices of an ethnic group as well as the dominant cultural attitudes, values and beliefs of an ethnic group. The role of culture in entrepreneurship and economic development has been studied from a variety of academic perspectives [Dana, 2007]. The elements of culture that have been measured in research and statistical reports include:

- entrepreneurship as a desirable career choice,

- equalizing the standard of living in the society,

- high-status successful entrepreneurship and media attention for entrepreneurship. 
Cultural values in the U.S. have been in favor of self-employment and entrepreneurship. The country was inhabited by significant numbers of immigrants and there is a high rate of social mobility and a high degree of entrepreneurship. The American ethnic group and its culture are associated with liberty, egalitarianism, individualism, populism, laissez-faire, freedom/independence/self-direction, self-sufficiency, individualism, achievement, materialism, novelty/challenge/excitement, power/status/prestige, machiavellianism, tolerance for ambiguity and dogmatism. Americans manifest themselves not only in career choices but also in the entrepreneur's approach to opportunity identification or to network building [Morris, Schinduhutte, 2005]. The lack of feudal past of the U.S. States has created a favorable socio-cultural context for adopting innovation and entrepreneurship. A proinnovation culture stimulating innovation among the entrepreneurs is supported by the educational programs and initiatives and a modern and coherent system of technology transfer and commercialization of knowledge. This way the cultural norms, expectations, and social sanctions related to the social role of entrepreneur encourage innovation. The U.S. has one of the highest rates of innovative entrepreneurship across the innovation-driven economies and New York and Ohio are the leaders in this measure whereas California has the highest innovation rates as it is the world capital of Internet companies [GEM, 2015]. In the U.S. an entrepreneurial culture is sometimes referred to the social capital (support) of entrepreneurs who tend to develop the skills, experience and capital that are the highly valued and necessary tools to founding and managing high growth enterprises. Networks and relationships are the crucial business facilitator, especially in the U.S., where a failure in business is seen as a positive learning experience.

\section{Concluding remarks}

Summing up the above considerations, it is clear that both social and cultural factors play important role and highly influence the stimulation of American entrepreneurship development. Numerous researchers prove that entrepreneurs are shaped by the factors of their socio-cultural environment and entrepreneurship is a social process that is culturally and historically determined. The enterprise development determinants related to entrepreneurs themselves are associated with

Figure 8 Entrepreneurs with a post-secondary degree and with graduate experience in the U.S. and its selected states, 2015

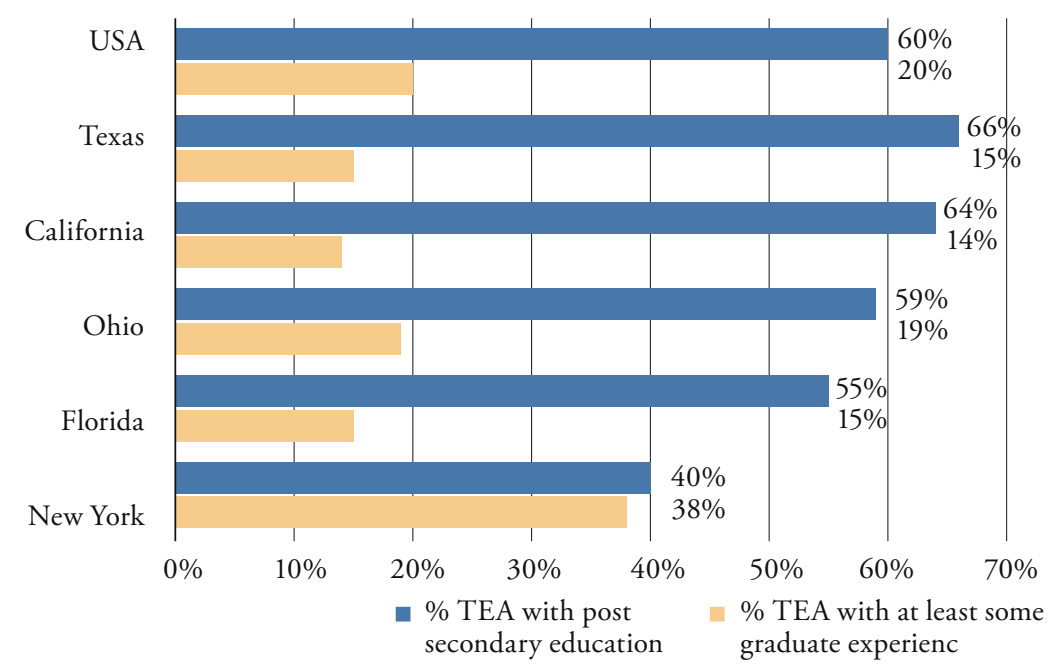


demographic factors such as age, gender, knowledge/know-how, vocational education and experience as well as cultural factors. The personal and national traits of the entrepreneur such as: risk aversion, motivation, persistence in pursuit of goals, and managerial competences, are significant. They influence the way the business is developed and they are reflected in key variables used in traditional entrepreneurial studies like gender, race, age and education (social measures).

The U.S. is an unusual country, and its short history is full of the major events that shaped its character and entrepreneurial environment. Individualism is a central feature of the U.S. culture and the entrepreneurs enjoy a high status. Most entrepreneurship is opportunity-driven rather than necessity-based. Women are starting businesses at a greater rate than in many other innovation-driven economies. Within the last decade the gap in expectations of men and women for growing a business has narrowed significantly. Women have not had equal access to financial markets due to the systemic bias against women business owners. They are more likely to outperform their men counterparts in meeting crowdfunding goals and they have been trending towards alternative lending sources for access to capital.

Ethnic entrepreneurship will have a significant impact on both the U.S. and the global economy in the coming decades and immigrants are twice as likely to be entrepreneurs compared to nativeborn Americans. The racial diversity of small business owners is increasing. A substantial proportion of African Americans-owned businesses are less successful, have lower profits and higher closure rates and business receipts are still dominated by white-owned enterprises. As far as the access to financing is concerned there are some racial and ethnic gaps as well.
Blacks and Hispanics have lower wealth levels than whites, and lower equity to develop their businesses.

Demographics is also one of the most important issues affecting entrepreneurship, however, there can be no definite connection between demography and aggregate entrepreneurship. Intentions to engage in entrepreneurial activity by different age groups in the U.S. are high. The country can expect a slowing labor force growth within the next several decades. An aging population tend not to become new entrepreneurs, nevertheless, there are reasons to expect that entrepreneurship may increase. One of them is that demographic trends create numerous entrepreneurial opportunities.

The majority of entrepreneurs in the U.S. are highly educated and $80 \%$ of them have a college degree or higher level of education. Higher levels of education increase the probability of becoming selfemployed and tertiary education has a positive influence on entrepreneurship by its contribution to the higher level of business owners' self-confidence, lower perceived risk and enhanced human capital. Moreover, human capital has a direct influence on the entrepreneur's ability to secure financial capital for business ventures. It has been evidenced that an added year of education raises entrepreneurial profits by $6.1 \%$ in developed countries. High tech firms based in the U.S. have the highest education levels and those with teams and owners with higher education levels are more likely to apply for a new bank loan. Racial disparities in education levels of business owners lead to racial disparities in business outcomes.

There is a clear evidence that culture has a significant influence on the U.S. entrepreneurial landscape. The cultural context influences the ways of thinking about business and cultural values in the U.S. have been in favor of self-employment and entrepreneurship. The U.S. business- 
men manifest themselves in career choices and the entrepreneur's approach to opportunity identification or to network building and an entrepreneurial culture is sometimes referred to the social capital of entrepreneurs. The cultural norms, ex- pectations, and social sanctions related to the social role of entrepreneur encourage innovation. Ethnicity affects the attitudes and behavior of American entrepreneurs and culture influences the entrepreneurial attitudes of the U.S. citizens.

\section{Bibliography:}

1. Agarwal R.R., Echambadi F.A., Sarkar M. [2004], Knowledge Transfer through Inheritance: Spin-out Generation, Development and Performance, "Academy of Management Journal", No. 47.

2. Akpor-Robaro M.O. [2012], The impact of socio-cultural environment on entrepreneurial emergence: A theoretical analysis of Nigerian society "European Journal of Business and Management", Vol. 4(16).

3. Alvarez C., Urbano D. [2011], Una década de investigación basada en el GEM, "Logros y Retos, Academia Revista Latinoamericana de Administración”, No. 46.

4. Arasti Z., Pasvishe F.A., Motavaseli M. [2012], Normative Institutional Factors Affecting Entrepreneurial Intention in Iranian Information Technology Sector, "Journal of Management and Strategy", No. 3(2).

5. Arun S., Arun T., Borooah V.K. [2004], The Effect of Career Breaks on the Working Lives of Women, "Feminist Economics", Vol. 10(1).

6. Audretsch D.B. [2012], Determinants of High-Growth Entrepreneurship, report prepared for the OECD/DBA International Workshop on High-growth firms: local policies and local determinants.

7. Azim M.T. [2008], Socio-cultural environment for entrepreneurship development in Bangladesh, "Journal of Bangladesh Studies", Vol. 10(1).

8. Backman M., Karlsson C. [2013], Determinants of entrepreneurship. Is it all about the individual or the region?, Centre of Excellence for Science and Innovation Studies (CESIS) Electronic Working Paper Series Paper, No. 338.

9. Baum J.R., Locke E.A. [2004], The Relationship of Entrepreneurial Traits, Skill, and Motivation to Subsequent Venture Growth, "Journal of Applied Psychology", No. 89.

10. Baum J.R., Locke, E.A., Smith, K.G. [2001], A Multidimensional Model of Venture Growth, "Academy of Management Journal", Vol. 44(2).

11. BC [2016], The state of small business in America 2016, report, Babson College.

12. BERR [2008], High Growth Firms in the United Kingdom: Lessons from an Analysis of Comparative UK Performance, "BERR Economics Paper", No. 3.

13. Bird B., Brush C. [2002], A gendered perspective on organizational creation, "Entrepreneurship Theory and Practice", No. 26.

14. Boggs W.B., [2004], TQM and organizational culture: a case study, "The Quality Management Journal", Vol. 11(2).

15. Bradford W.D., Mijid N. [2016], Kauffman Compilation, "Research on Race and Entrepreneurship".

16. Bruni A., Gherardi S., Poggio B. [2004], Doing gender, doing entrepreneurship: An ethnographic account of intertwined practices, "Gender, Work \& Organization", Vol. 11(4).

17. Brush C.G., Carter N.M., Gatwood E.J., Greene P.G., Hart M. [2004], Clearing the Hurdles: Women building high growth business, NJ, Prentice Hall, Englewood Cliffs. 
18. Brush C., Manolova T. [2004], Household Structure, in: Handbook of Entrepreneurial Dynamics: The Process of Business Creation, Gartner W.B., Shaver K., Carter N., Thousand Oaks, Sage Publications.

19. Brzozowska A. [2016], Teorie przedsiębiorczości, in: Zarządzanie, organizacje i organizowanie - przegląd perspektyw teoretycznych, WN Wydziału Zarządzania, Uniwersytet Warszawski.

20. Casson M., Godley A. [2000], Cultural Factors in Economic Growth, USA, Springer Publishing.

21. Castrogiovanni G.J., Urbano D., Loras J. [2011], Linking corporate entrepreneurship and human resource management in SMEs, "International Journal of Manpower", Vol. 32(1).

22. Cierniak-Szóstak E. [2008], Wizerunek polskiego przedsiębiorcy jako element społecznej legitymizacji I delegitymizacji nowego tadu, „Nierówności społeczne a wzrost gospodarczy”, nr 12.

23. Coduras A., Urbano D., Rojas A., Martínez S. [2008], The relationship between university support to entrepreneurship with entrepreneurial activity in Spain: A GEM data based analysis, "International Advances in Economic Research", Vol. 14(4).

24. Dana L. [2007], Handbook of Research on Ethnic Minority Entrepreneurship: A Co-evolutionary View on Resource Management, UK, Edward Elgar Publishing Limited.

25. David F.R. [2013], Strategic Management. Concepts and Cases. A Competitive Advantage Approach, 14th ed., Edinburgh Gate, Pearson Education Limited.

26. Davidsson P., Honig B. [2003], The role of social and human capital among nascent Entrepreneurs, "Journal of Business Venturing", Vol. 18(3).

27. Fairlie R.W., Morelix A. [2015], The Kauffman Index Startup Activity, Ewing Marion Kauffman Foundation, http://www.kauffman.org.

28. Fairlie R.W., Robb A.M. [2008], Race and Entrepreneurial Success Black-, Asian-, and White-Owned Businesses in the United States, Massachusetts, The MIT Press Cambridge.

29. Fairlie R.W., Robb A.M., Hinson D. [2010], Disparities in Capital Access between Minority and NonMinority-Owned Businesses, MBD Agency, U.S. Department of Commerce.

30. Fetsch E. [2016], Does Racial Wealth Disparity Hinder Entrepreneurship?, "Growthology. Exploring Entrepreneurship Research”.

31. FitzRoy P.T., Hulbert J.M., Ghobadian A. [2012], Strategic Management. The challenge of creating value, 2nd edition, Abingdon, Routledge.

32. GEM [2015], Global Entrepreneurship Monitor GEM, National Entrepreneurial Assessment for the United States of America, 2015.

33. Gnyawali D.R., Fogel D.S. [1994], Environments for Entrepreneurship Development: Key Dimensions and Research Implications, "Entrepreneurship: Theory \& Practice", Vol. 18(4).

34. Godowska M. [2011], Spoteczno-kulturowe uwarunkowania przedsiębiorczości kobiet w Polsce, „Państwo i Społeczeństwo", $\mathrm{Nr} 4$.

35. 35. Goodwin M. [2015], The Myth of the Tech Whiz Who Quits College to Start a Company, "Harvard Business Review”.

36. Gupta V., MacMillan I.C., Sure G. [2004], Entrepreneurial leadership: developing and measuring a cross-cultural construct, "Journal of Business Venturing”, Vol. 19(2).

37. Hall E.T. [1976], Beyond Culture, Garden Citi, New York, Harper and Row.

38. Hao S. [2015], An analysis of American individualism culture, www.haosuyawen.wordpress. com/2015/02/19, retrieve 1/06/2017.

39. Harding R. [2002], Plugging the knowledge gap: an international comparison of the role for policy in the venture capital market, "Venture Capital", No. 1.

40. Hayton J.C., George G., Zahra S.A. [2002], National Culture and Entrepreneurship: A Review of Behavioral Research. Entrepreneurship, “Theory \& Practice”, Vol. 26(4).

41. Hipple S.F. [2010], Self-employment in the United States, "Monthly Labor Review”, Vol. 133(9).

42. Hofstede G. [1980], Culture's Consequences: International Differences in Work-related Values, Beverly Hills, CA, Sage Publications. 
43. Hofstede G. [1995], Managerial values, in: Cross-cultural Management, T. Jackson (ed.), New York, McGraw-Hill.

44. Inglehart R. [1997], Modernization and post-modernization, Cultural, economic, and political change in 43 societies (Vol. 19). NJ, Princeton University Press.

45. Janczewski J. [2005], Criteria and measures of entrepreneurship in small business, "EntrepreneurshipEducation”, No. 1, Akademia Pedagogiczna im. KEN w Krakowie.

46. Jiméneza A., et al. [2015], The impact of educational levels on formal and informal entrepreneurship, "Business Research Quarterly", Vol. 18.

47. Karoly L.A., Zissimopoulos J. [2004], Self-employment among older U.S. workers, "Monthly Labor Review", Vol. 127(7).

48. Karpowicz J. [2013], Wsparcie ze środków publicznych a rozwój matych i średnich przedsiębiorstw $w$ Niemczech, PhD Dissertaion, Uniwersytet w Białymstoku.

49. Kelley D.J., et al. [2014], United States Report Global Entrepreneurship Monitor, National Entrepreneurial Assessment for the United States of America.

50. King G., Soneji S. [2011], The Future of Death in America, "Demographic Research", Vol. 25.

51. Klepper S. [2009], Silicon Valley, a Chip off the Old Detroit Bloc, in: Entrepreneurship, Growth, and Public Policy, Acs Z.J., Audretsch D.B., Strom R., New York, Cambridge University Press.

52. Kolstad I., Wiig A. [2011], Education and entrepreneurial success, Department of Economics, Trinity College, Dublin.

53. Knörr H., Álvarez C., Urbano D. [2013], Entrepreneurs or employees: A cross-cultural cognitive analysis, "International Entrepreneurship and Management Journal”, Vol. 9(2).

54. Liñán F., Urbano D., Guerrero M. [2011], Regional variations in entrepreneurial cognitions: start-up intentions of university students in Spain, "Entrepreneurship and Regional Development", Vol. 23(3-4).

55. Maestas N., Zissimoupoulos J. [2010], How Longer Work Lives Ease the Crunch of Population Aging, "Journal of Economic Perspectives", Vol. 24, No. 1.

56. Marshall M.I., Samal A. [2006], The Effect of Human and Financial Capital on the Entrepreneurial Process: An Urban-Rural Comparison of Entrepreneurs in Indiana, Department of Agricultural Economics, Purdue University.

57. MBDA [2016], Fact sheet US Minority-owned business, Minority Business Development Agency, U.S. Department of Commerce, www.mbda.gov, retrieve 1/06/2017.

58. Morris M., Schindehutte M. [2005], Entrepreneurial Values and the Ethnic Enterprise: An Examination of Six Subcultures, "Journal of Small Business Management”, Vol. 43(4).

59. Mueller S.L., Thomas A.S. [2000], Culture and Entrepreneurial Potential: a Nine Country Study of Locus of Control and Innovativeness, "Journal of Business Venturing”, Vol. 16(1).

60. Noguera M., Álvarez C., Urbano D. [2013], Socio-cultural factors and female entrepreneurship, "International Entrepreneurship Management Journal”, Vol. 9(2).

61. NWBC [2015], 10 Million Strong. The tipping women's entrepreneurship, Annual Report 2015, National Women's Business Council, USA.

62. OECD/DBA [2012], Determinants of High-Growth Entrepreneurship, report prepared for the OECD/ DBA International Workshop: High-growth firms: local policies and local determinants, Copenhagen.

63. Pfau-Effinger B. [2004], Development of Culture, Welfare States and Women's Employment in Europe, Aldershot, Ashgate.

64. Pofeldt E. [2017], Why women entrepreneurs will be the economic force to reckon with in 2017, CNBC, https://www.cnbc.com, retrieve 3/06/ 2017.

65. Polak K., Haber A. [2014], Polish look at entrepreneurship, "Harvard Business Review".

66. Robb A.M. [2013], Access to Capital among Young Firms, Minority-owned Firms, Women-owned Firms, and High-tech Firms, U.S. SBA, Office of Advocacy.

67. Robb A.M., Robert W.F., Robinson D.T. [2009], Financial Capital Injections Among New Black and 
White Business Ventures: Evidence from the Kauffman Firm Survey, University of California.

68. Rokita A. [2015], Biznes -szansa wieku średniego, www.pi.gov.pl, retrieve June 1, 2017.

69. Román C., Congregado E., Milán J.M. [2013], Start-up incentives: Entrepreneurship policy or active labour market programme?, "Journal of Business Venturing”, Vol. 28(1).

70. Russell R.D. [2004], Cultural Influences on Entrepreneurship: Implications for the Emergence of New Ventures in Latin America, "Journal of Transnational Management", Vol. 10(1).

71. Safin K. [2003], Zarządzanie mata firma, Wrocław, Wydawnictwo AE we Wrocławiu.

72. SBA [2013], Demographic Characteristics of Business Owners and Employees: 2013, U.S. Small Business Administration, http://www.sba.gov.

73. SBA [2015], Small business Profiles for the States and Territories, Advocacy: the voice of small business in government, U.S. Small Business Administration, https://www.sba.gov.

74. SBA [2016], Small Business Profiles for the States and Territories, U.S. Small Business Administration, https://www.sba.gov.

75. Shane S. [2003], Prior Knowledge and the Discovery of Entrepreneurial Opportunities, "Organization Science", University of Maryland.

76. Shane S., Venkataraman, S. [2000], The promise of entrepreneurship as a field of research, "Academy of Management Review", Vol. 25(1).

77. Skawińska E. [2012], Konkurencyjność przedsiębiorstw - nowe podejście, Warszawa, PWN.

78. Slivinski S. [2015], Bootstraps Tangles in Red Tape: How State Occupational Licensing Hinders LowIncome Entrepreneurship, "Policy Report", No. 272, Arizona State University.

79. Stangler D., Spulber D. [2013], The Age of the Entrepreneur: Demographics and Entrepreneurship, Ewing Marion Kauffman Foundation, http://www.kauffman.org, retrieve 3/06/2017.

80. Sztompka P. [1998], Zaufanie: podstawa relacji spotecznych, „Krytyczna teoria organizacji”, nr 3.

81. Thornton P., Ribeiro-Soriano D., Urbano D. [2011], Socio-cultural factors and entrepreneurial activity: An overview, "International Small Business Journal", Vol. 29(2).

82. Toossi M. [2012], Labor force projections to 2020: a more slowly growing workforce, "Monthly Labor Review", January.

83. Trompenaars F., Hampden-Turner C. [2012], Riding the Waves of Culture:Understanding Diversity in Global Business, 3rd edition, New York, McGraw Hill.

84.van der Sluis J., van Praag M. [2008], Education and entrepreneurship selection and performance: A review of the empirical literature, "Journal of Economic Surveys", Vol. 22(5).

85. Wadhwa V., Freeman R., Rissing B. [2008], Education and Tech Entrepreneurship, Kauffman, The Foundation of Entrepreneurship.

86. Zeffane R. [2014], Does collectivism necessarily negate the spirit of entrepreneurship?, "International Journal of Entrepreneurial Behavior \& Research”, Vol. 20(3).

PhD Robert Rumiński, Faculty of Management and Economics of Services, Department of Banking and Comparative Finance, University of Szczecin. 